Vol. 1 No. 2 Desember 2021, e-ISSN : 2807-8659 | p-ISSN : 2807-8829

\title{
PENGEMBANGAN APLIKASI TELEGRAM PADA KEGIATAN PRAMUKA DI MASA PANDEMI COVID-19
}

\author{
WAKHIDIN SHODIQ, FAUZI \\ UIN SAIZU Purwokerto \\ Email : wakhid.dini@gmail.com, fauzi@uinsaizu.ac.id
}

\begin{abstract}
ABSTRAK
Penelitian ini menggunakan prosedur pengembangan yang menghasilkan desain produk berupa pengembangan media pembelajaran berbasis IT dengan menggunakan Aplikasi Telegram. Produk ini peneliti kembangkan dengan menggunakan langkah-langkah penelitian dari Borg and Gall dan Model ASSURE. Produk yang dikembangkan dalam penelitian ini yaitu media pembelajaran berbasis IT menggunakan Aplikasi Telegram. Dengan adanya keterbatasan waktu, maka peneliti membatasi langkah-langkah prosedur pengembangan hanya pada 6 (enam) langkah, yaitu (1) potensi dan masalah, (2) pengumpulan data, (3) desain produk, (4) validasi, (5) revisi desain, dan (6) uji coba. Tujuan penelitian kali ini untuk mengetahui efektifitas media pembelajaran berbasis IT pada Aplikasi Telegram yang digunakan dalam kegiatan Lajutin Pendidikan Kepramukaan di Ambalan Bhira SMA Negeri 3 Purwokerto pada masa pandemi Covid-19.
\end{abstract}

Kata Kunci : Aplikasi Telegram, Pendidikan Kepramukaan

ABSTRACT

This research uses development procedures that result in product design in the form of IT-based learning media development using the Telegram Application. This product researchers developed using research steps from Borg and Gall and THE ASSURE Model. The product developed in this study is an IT-based learning medium using the Telegram Application. With time constraints, researchers limit the steps of development procedures to only 6 (six) steps, namely (1) potential and problems, (2) data collection, (3) product design, (4) validation, (5) design revision, and (6) trials. The purpose of this research is to find out the effectiveness of IT-based learning media in the Telegram Application used in scouting education activities at Ambalan Bhira Sma Negeri 3 Purwokerto during the Covid-19 pandemic.

Keywords: Telegram Application, Scouting Education

\section{PENDAHULUAN}

Pandemi Covid-19 melanda seluruh dunia di akhir tahun 2019. Data dari WHO di akhir Maret 2020 menunjukkan data bahwa terdapat kasus yang terkonfirmasi sejumlah 1.528 kasus dan 136 kasus kematian dengan tingkat moralaitas 8,9\% yang merupakan tertinggi di Asia Tenggara. Sehingga virus Covid-19 ditetapkan sebagai pandemi yang perlu di waspadai mendunia. Upaya mencegah pandemi ini supaya tidak tersebar luas, belajar dari rumah bagi pendidik dan peserta didik merupakan tindak lanjut dari anjuran pemerintah seperti mulai dari social distancing sampai physical distancing. Pendapat Pramudiya (2020) pengertian social distancing artinya semua individu harus menjaga jarak satu dengan yang lainnya.

Sehingga dampak dari pendemi covid-19 terjadi dalam semua sisi kehidupan termasuk di Indonesia. Salah satunya dunia pendidikan dalam sistem pembelajaran daring atau online jarak jauh. Hampir semua proses pembelajaran menggunakan media online, termasuk dalam kegiatan ekstrakurikuler sebagai salah satu kegiatan yang terdampak dari pendemi covid 19. Menurut Suyanto (2010) menyampaikan bahwa kegiatan esktrakurikuler merupakan kegiatan pendidikan yang dilakukan diluar jam pelajaran tatap muka yang dilaksanakan baik didalam maupun diluar lingkungan sekolah, dalam rangka memperluas pengetahuan, meningkatkan ketrampilan dan menginternasilasi nilai-nilai atau aturan-aturan agama serta norma-norma sosial baik lokal, nasional maupun global guna membentuk insan yang paripurna. 
Suyahman (2020) menyebutkan bahwa Gerakan Pramuka merupakan bagaian dari oragnisasi kemasyarakatan yang secara aktif dan kreatif melakukan pendidikan kepramukaan sesuai dengan jenjang, jenis dan usia peserta didik melalui visi Gerakan Pramuka sebagai wadah pilihan utama dan solusi handal masalah kaum muda.

Namun dikarenakan pandemi covid-19 kegiatan pendidikan kepramukaan tidak boleh dilaksanakan secara offline di alam terbuka, sehingga agar proses pendidikan kepramukaan tersebut tetap bisa dilaksanakan dengan suasana yang menyenangkan walaupun terbatas, maka kegiatan kepramukaan di sekolah hanya bisa dilaksanakan dengan memanfaatkan media online yang sudah ada. Banyak media online yang dapat digunakan dalam masa pendemi covid-19, di antaranya aplikasi Whatsapp, Wahtsapp Group, Google Classroom, Telegram, E-mail, Google Form, Google Meet, Zoom, Webex Meet dll.

Merujuk pada survei kebutuhan salah satu media pembelajatan berbasis IT dipilih dan digunakan adalah Aplikasi Telegram. Telegram dengan fitur bot atau robot diprogram dengan berbagai perintah untuk menjalankan serangkaian instruksi yang diberikan oleh pengguna yang dioperasikana oleh perangkat lunak yang memiliki fitur AI. (Ariskisaputri. 2019)

Fifit Fitriansyah (2020) menyampaikan bahwa guna mendukung proses pembelajaran, penggunaan salah satu media online Telegram merupakan salah satu sumber komunikasi yang memudahkan siswa untuk mendapatkan informasi melalui kelompok. Kemudian Rahmat Hidayat dkk (2021) juga menyampaikan tentang fungsi Quiz Bot Telegram menjadi salah satu pilihan menarik bagi guru untuk mempermudah proses pembelajaran di masa pandemi.

Meninjau masalah di atas, maka peneliti mengembangkan penggunaan media pembelajan berbasis IT Aplikasi Telegram pada kegiatan Latihan Rutin Pendidikan Kepramukaan karena harus tetap dilaksanakan sebagai salah satu bentuk pembentukan karakter peserta didik di satuan pendidikan menengah atas maupun menengah kejuruan. Alasan memilih peserta didik SMA atau SMK sebagai anggota Pramuka Penegak karena saat ini mereka sudah terbiasa menggunakan media online.

\section{METODE PENELITIAN}

Pada penelitian ini menggunakan metode penelitian dan pengembangan. Menurut Sugiyono (2009) metode penelitian dan pengembangan merupakan metode penelitian yang digunakan untuk menghasilkan produk tertentu dan menguji keefktifan produk tersebut. Menurut Brog and Gall (1983) educational research and development is a process used to develop and validate educational product, artinya bahwa penelitian dan pengembangan adalah sebuah proses yang digunakan untuk mengembangkan dan memvalidasi produk pendidikan. Dan hasil dari penelitian pengembangan tidak hanya pengembangan produk yang sudah ada, melainkan juga untuk menemukan pengetahuan atau jawaban atas permasalahan praktis. Untuk dapat menghasilkan produk tertentu, digunakan penelitian yang bersifat analisis kebutuhan (digunakan metode survei atau kualitatif) dan untuk menguji keefektifan produk tersbut supaya dapat berfungsi di masyarakat luas, maka diperlukan penelitian untuk menguji kefektifan produk tersbut (digunakan metode eksperimen).

Adapun langkah-langkah prosedur pengembangan akan disajikan dalam gambar 1 


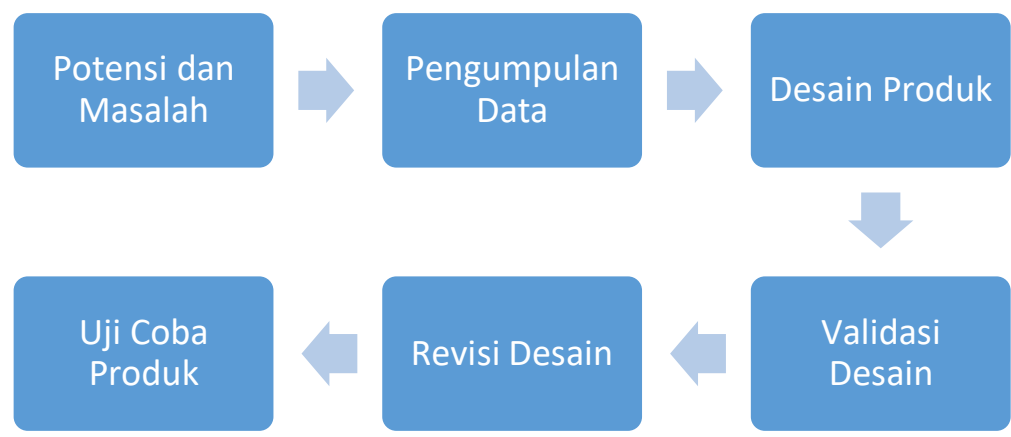

\section{Gambar 1. Bagan Langkah-langkah Penggunaan Metode R \& D}

Jenis penelitian ini mengembangkan produk berupa aplikasi Telegram pada kegiatan Latihan Rutin Pendidikan Kepramukaan di tingkat SMA/SMK. Mengacu pada tahapan laangkah-langkah prosedur pengembangan seperti pada bagan di atas, maka dalam penelitian ini akan dibatasai pada enam (enam) langkah, yaitu (1) Potensi dan Masalah, (2) Pengumpulan Data, (3) Desain Produk, (4) Validasi Produk, (5) Revisi Desain, dan (6) Uji Coba Produk.

Penelitian ini menggunakan prosedur pengembangan media pembelajaran berbasis IT dengan menggunakan Aplikasi Telegram. Produk ini peneliti kembangkan dengan menggunakan langkah-langkah penelitian dari Borg and Gall dan model ASSURE.

Penelitian pengembangan ini menggunakan instrumen penelitian berupa daftar pertanyaan wawancara dan kuesioner melalui Google Form. Daftar pertanyaan wawancara digunakan untuk menganalisis kebutuhan terhadap media pembelajaran berbasis IT dengan menggunakan Aplikasi Telegram pada kegiatan Latihan Rutin Pendidikan Kepramukaan tingkat SMA/ SMK.

Teknik pengumpulan data yang digunakan ini merupakan wawancara dan kuesioner melalui Google Form.

a. Wawancara

Wawancara dengan tujuan untuk melakukan survei kebutuhan terkait dengan media pembelajaran berbasis IT. Peneliti melakukan wawancara kepada Pembina Pramuka dan Perwakilan Dewan Ambalan di SMA Negeri 3 Purwokerto. Data di analisis untuk mendapatkan informasi terkait kebutuhan pembina dan dewan ambalan untuk media pembelajaran berbasis IT pada kegiatan Latihan Ruitn Pendidikan Kepramukaan.

b. Kuesioner

Teknik pengumpulan data berikutnya berupa kuesioner dengan Google Form, dengan tujuan untuk memvalidasi dan membantu peneliti dalam melakukan revisi atas penggunaan media pembelajaran berbasis IT berupa Aplikasi Telegram, guna mengetahui kekurangan dan kelebihan dari penggunaan aplikasi tersebut.

Data penelitian ini di analisis secara kualitatif dan kauntitatif dengan penjelasan sebagai berikut :

a. Data Kualitatif

Data kualitatif berupa komentar yang dikemukakan oleh Pembina Pramuka ,Perwakilan Dewan Ambalan dan Anggota Pramuka di Ambalan Bhira SMA Negeri 3 Purwokerto. Data tersebut di analisis sebagai dasar untuk memperbaiki dan mengetahui kelayakan penggunaan produk yang di hasilkan.

b. Data Kuantitatif

Data kuantitatif merupakan data skor dari penilaian Pembina Pramuka, Perwakilan Dewan Ambalan dan Anggota Pramuka di Ambalan Bhira SMA Negeri 3 Purwokerto yang di analisis sebagai dasar dari hasil penilaian kuesioner di ubah menjadi interval. Skala penilaian terhadap media pembelajaran berbasis IT Aplikasi Telegram yang 
dikembangkan yaitu Sangat Baik (4), Baik (3), Kurang Baik (2), Sangat Kurang Baik

(1). Perolehan skor dari penilaian validator dihitung dengan menggunakan skala Likert.

Sedangkan skala pengukuran untuk tingkat kebaikan ; 1 (Sangat Kurang Baik), 2 (Lurang Baik), 3 (Baik), 4 (Sangat Baik). Dan berikut adalah Rumus Skala Likert untuk mengetahui interval penilaian skala numerik.

$$
\begin{array}{ll}
\text { Rumus : } & \mathrm{RS}=(\mathrm{m}-\mathrm{n}) / 4 \\
& \mathrm{RS}=(4-1) / 4 \\
\mathrm{RS} & =0,75
\end{array}
$$

Tabel. 1 Skala Likert

$\begin{array}{lll}\text { Sangat Baik } & \text { SB } & 3,25-4 \\ \text { Baik } & \text { B } & 2,5-<3,25 \\ \text { Kurang Baik } & \text { KB } & 1,75-<2,5 \\ \text { Sangat Kurang Baik } & \text { SKB } & 1-<1,75\end{array}$

Dari hasil perhitungan interval di atas, kemudian dapat dibuat tavel penghitungan hasil validasi terhadap kualitas dari media pembelajaran berbasis IT Aplikasi Telegram dengan skala Likert seperti berikut :

Skor : Jumlah Total dari masing-masing variabel

Rata-rata : Skor Penilaian $(\mathrm{SB}=4)+(\mathrm{B}=3)+(\mathrm{KB}=2)+(\mathrm{SKB}=1)$

Hasil dari perhitungan skor masing-masing validasi yang dilakukan akan dicari rata-rata skor perolehannya, kemudian dapat dikonversikan dari data kuantitatif ke data kaulitatif dalam kategori tertentu seperti yang tertera pada tabel slor skala Likert Empat.

\section{HASIL DAN PEMBAHASAN}

1. Data Hasil Validasi dan Uji Coba Aplikasi Telegram oleh Pembina Pramuka, Perwakilan Dewan Ambalan dan Anggota Pramuka di Ambalan Bhira SMA Negeri 3 Purwokerto

Media pembelajaran berbasis IT dengan penggunaan Apliaksi Telegram di validasi oleh Pembina Pramuka, Dewan Ambalan dan Anggota Pramuka. Yang menjadi validator pembina Pramuka Kakak F dan Kakak L , dari 57 anak mewakili Dewan Ambalan dan Anggota Pramuka. Validasi oleh Kakak F dan L dilakukan pada tanggal 9 November 2021. Dan Validasi oleh Dewan Ambalan dan Adik-adik Anggota Pramuka pada tanggal 16 November 2021. Aspek yang dinilai pada media pembelajaran berbasis IT menggunakan Apliaksi Telegram yaitu : 1) Aspek Konten dan Isi, 2) Aspek Tampilan, 3) Aspek Penggunaan dan Penyajian, 4) Aspek Bahasa, 5). Kesan .

Berdasarkan validasi oleh Pembina Pramuka Kakak F memberi skor rata-rata 3.20 dengan kategori "Baik", dan Kakak L memberi skor rata-rata 3.00 dengan kategori "Baik" pada penggunaan Aplikasi Telegram dan layak digunakan pada Lajutin Pramuka. Validasi oleh 57 anak perwakilan Dewan Ambalan dan Anggota Pramuka memberi skor rata-rata 3,14 dengan kategori "Baik" dan layak digunakan pada Lajutin Pramuka.

Berikut tabel hasil penelitan validasi dari Pembina Pramuka, Dewan Ambalan dan beberapa Anggota Pramuka. 
Tabel. 2 Rerata Hasil Penggunaan Aplikasi Telegram

\begin{tabular}{llll}
\hline No. & Validator & \multicolumn{2}{l}{ Penggunaan Aplikasi Telegram } \\
\cline { 3 - 4 } & & Skor & Kategori \\
\hline 1 & Kakak F & 3,20 & Baik \\
2 & Kakak L & 3,00 & Baik \\
3 & DA \& Anggota & 3.14 & Baik \\
\hline & Jumlah & 9,34 & \\
Rerata & 3,11 & \\
(Jumlah total validator) & & Baik \\
\hline Kategori & & \\
\hline
\end{tabular}

2. Penggunaan Aplikasi Telegram pada Kegiatan Latihan Rutin (Lajutin) Kepramukaan di Ambalan BHIRA SMA Negeri 3 Purwokerto pada masa Pandemi Covid-19.

Pada penerapan pelaksanaan kegiatan pendidikan kepramukaan di Ambalan Bhira SMA Negeri 3 Purwokerto yang disebut dengan Laihan Jum'at Rutin (Lajutin) pada masa pandemi covid-19 terdapat tiga langkah, yaitu pertama tahap persiapan, kedua tahap pelaksanaan, tiga tahap penutupan.

a. Tahap Persiapan

Tahap mempersiapkan apa saja yang diperlukan antara peserta didik sebagai anggota ambalan dengan dewan ambalan sebagai pengelola kegiatan dana pembina pramuka sebagai penanggungjawab kegiatan. Hal yang perlu dipersiapkan dalam kegiatan pendidikan kepramukaan Lajutin dengan aplikasi Telegram sebagai medianya adalah :

1) Grup Chat Telegram

Dewan ambalan harus membuat satu grup chat yang berisi pembina, dewan ambalan dan peserta didik sebagai anggota ambalan. Grup Chat ini digunakan untuk mempermudah interaksi antara semua anggota ambalan dalam mengikuti Lajutin.

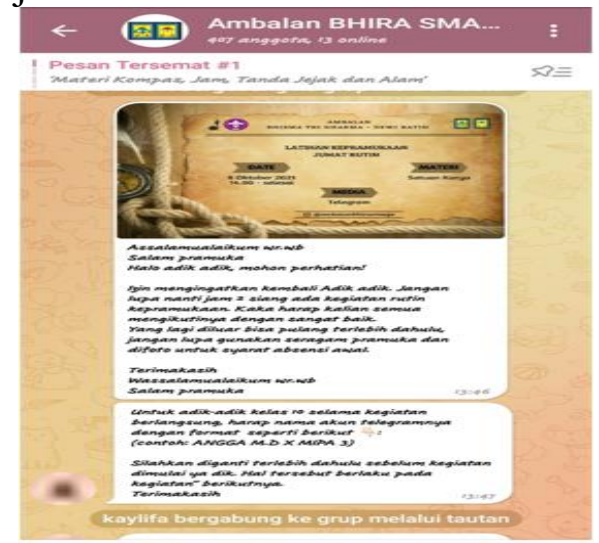

\section{Gambar. 2 Info Lajutin Pramuka melalui Chat Telegram}

2) Materi Latihan

Materi latihan ini meliputi berkas dan file yang didalamnya mencakup materi yang akan disampaikan berupa word, powerpoint atau video dan voic note yang dikirinkan melalui apliaksi telegram. 
3) Daftar Hadir Anggota Ambalan

Dewan ambalan mempersiapkan daftar hadir anggota ambalan yang digunakan untuk mengukur kedisiplian dalam mengikuti Lajutin secara online. Adapun teknisnya melalui chat langsung di aolikasi telegram, juga bisa melalui aplikasi tambahan google form dan menggunakan fitur polling di aplikasi Telegram.

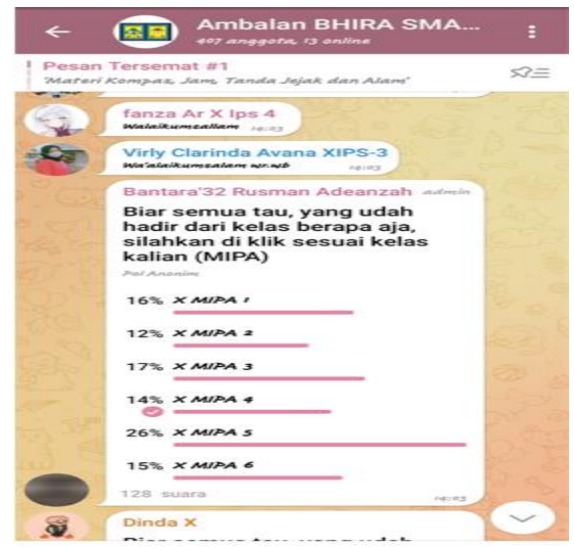

Gambar. 3 Absensi Lajutin melalui Chat Telegram

b. Tahap Pelaksanaan

Pada tahap pelaksanaan ini, terdapat beberapa teknis yang dapat dilakukan melalui apliaksi telegram ini, seperti melalui video yang ditautkan pada media apliaksi ketiga youtube, google video dan lainnya.

Dapat juga melalui pesan video yang dikirim langsung oleh pembina Pramuka atau dewan ambalan yang diinginkan di grup chat kepada peserta didik sebagai anggota ambalan.

Atau melalui fitur video call telegram yang dilakukan pembina Pramuka dalam memberikn sambutan membuka latihan dan menyampaikan materinya secara langsung.

Kemudian melanjtukan pembukaan latihan dengan menyampaikan lagu Indonesia Raya dan Hymne Satya Darma Pramuka pada chat melalui video yang sudah disiapkan. Dilanjutkan menyampaika materi baik secara online maupun dibagikan hardcopy melaluichat telegram.

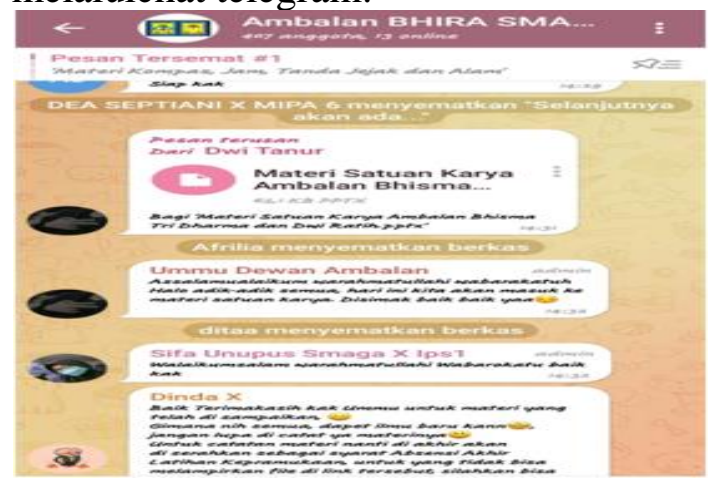

\section{Gambar 4. Penyampaia Materi Lajutin melalui Chat Telegram}

c. Tahap Penutupan

Tahap ini bertujuan untuk mengevaluasi pelaksanaan kegiatan Latihan Jum'at Rutin (Lajutin) yang dilakukan dengan Aplikasi Telegram. Dalam melaksanakan evaluasi dapat dilakukan dengan berbagai macam cara. Sebagaimana Bloom (1964) mengungkapkan dalam taksonominya, bahwa evaluasi adalah pengumpulan bukti secara sistematis untuk menentukan beberapa perubahan yang sebenarnya 
diperoleh dalam proses belajar yang dapat digunakan untuk menentukan jumlah/ banyaknya atau derajat dari perubahan individu.

Untuk mengevaluasi pelaksanan kegiatan pendidikan kepramukaan Latihan Jum'at Rutin (Lajutin) dilakukan antara lain dengan ; membuat penilaian berupa quis dengan mengguakan apliakasi google form atau fitur poling yang ada di aplikasi telegram.

Peserta didik selaku anggota Pramuka yang mengikuti kegiatan bisa langsung mengisi quis dan ada rewad yang diberikan oleh dewan ambalan.

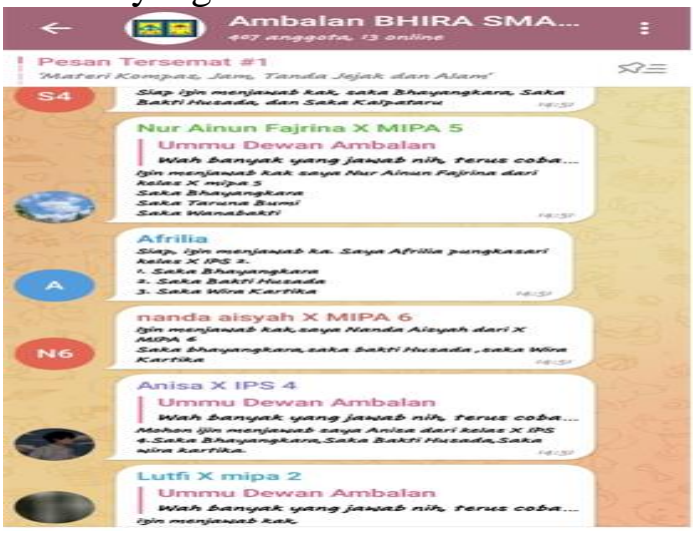

Gambar 5. Evaluasi Lajutin Menjawab Quiz

Selesai mengerjakan dan rewad yang diberikan ditutup dengan mendengarkan bersama lagu Bagimu Negeri yang dibagikan lewat chat. Kemudian ditutup dengan doa' oleh petugas dari dewan ambalan. Di akhiri dengan menyampaikan rencana materi yang akan disamapikan pada pertemuan berikutnya.

\section{Kelebihan dan Kekurangan Aplikasi Telegram pada Kegiatan Latihan Rutin} (Lajutin) Pendidikan Kepramukaan di Amba;an Bhira SMA Negeri 3 Purwokerto pada Masa Pandemi Covid-19

Media pembelajran berbasis IT dengan menggunakan Aplikasi Telegram pada kegiatan Latihan Jum'at Rutin (Lajutin) Pendidikan Kepramukaan pada masa pandemi covid-19 memilki kelebihan dan kekurangan. Kelebihanya antara lain yaitu :

a) Tidak peelu membutuhkan tempat atau ruangan dalam proses latihan

b) Latihan dapat dilaksanakan kapapun waktunya

c) Pembina atau dewan ambalan dapat berinteraksi secara langsung dengan peserta didik seperti saat tatap muka dengan menggunakan video call.

d) Pembina atau dewan ambalan dapat menampilkan materi melalui fitur share screen sehingga peserta didik dapat melihat materi yang sedang di sampaikan oleh pembina.

e) Aplikasi lebih ringan dibandingkan dengan media aplikasi lain yang membutuhkan bandwith lebih besar.

f) Evaluai melalui quiz di aplikasi membuat peserta didik lebih menarik untuk mengikutinya.

Sedangkan kekurangan Apliaksi Telegram pada kegiatan Lajutin Pendidikan Kepramuka di masa pandemi covid-19, yaitu secara teknis di antarnya :

a) Koneksi internet

b) Ketersediaan kuota internet peserta didik yang tidak mencukupi karena menggunakan apliaksi telegram membutuhkan bandwith yang lebih besar dibandingkan hanya untuk chat.

c) Keikutsertaan peserta didik sebagai anggota ambalan belum bisa $100 \%$, dikarenakan terkendala teknis. 
d) Terdapat kemalasan dan kebosanan peserta didik untuk mengikuti Lajutin dikarenakan sistem penyampaian materi monotn melalui media online. Mereka membutuhkan latihan secara langsung di alam terbuka, yang menarik dan menyenangkan.

Dengan demikian hasil penelitian membuktikan bahwa media pembelajaran berbasis IT dengan menggunakan Aplikasi Telegram yang divalidasi oleh Pembina Pramuka perwakilan Dewan Ambalan dan Anggota Pramuka, maka diperoleh data bahwa media pembelajaran berbaisi IT dengan menggunakan Aplikasi Telegram termasuk dalam kategori "Baik" dengan sekor rata-rata akhir yaitu 3,11 dan layak digunakan pada kegiatan Lajutin Pendidikan Kepramukaan di Ambalan Bhira SMA Negeri 3 Purwokerto yang dijabarkan pada tabel 2.

Telegram dirancang untuk memudahkan pengguna saling berkirim pesan, teks, audio, video, gambar dan sticker dengan aman (Fahana \& Ridho, 2018). Hasil penelitian ini tidak jauh berbeda dengan hasil penelitian yang dilakukana oleh Fifit Fitriansyah (2020) bahwa penggunaan telegram adalah sumber komunikasi yang memudahkan siswa untuk mendapatkan informasi melalui kelompok. Penelitian lain oleh Dhanan Abimanto (2021) menyampaikan bahwa penggunaan Aplikasi Telegram sebagai media pembelajaran speaking Bahasa Inggris sangat memudahkan pengajar dan pembelajar pada proses pembelajaran. Menurut hasil penelitian Ikhwan Nur Rois (2020) menyebutkan bahwa penerapan Aplikasi Telegram sebagai media pembelajaran Bahasa Arab Peminatan di MAN 1 Kulonprogo sudah sangat sesuai dengan kondisi masa pandemi covid-19. Dan menurut hasil penelitian Baroroh Indiani menyampaikan bahwa penggunaan media daring dalam proses pembelajaran merupakan salah satu solusi untuk mendukung anjuran belajar dari rumah dan mentaati physiccal distancing untuk memurus rantai covid-19 dapat dilaksanakan dengan baik.

\section{KESIMPULAN} berikut :

Berdasarkan hasil penelitian dan pembahasan, maka dapat disimpulkan sebagai

1. Penelitian Media Pembelajaran berbasis IT dengan menggunakan Aplikasi Telegram yang dikembangkan berdasarkan langkah penelitian dan pengembangan Berg and Gall dan Model Assure dengan prosedur terdiri dari 5 (lima) langkah, yaitu (a) potensi dan masalah, (b) pengumpulan data, (c) desain produk, (d) validasi, (e) Uji Coba telah dilaksanakan pada kegiatan Latihan Jum'at Rutin (Lajutin) Pendidikan Kepramukaan di Ambalan Bhira SMA Negeri 3 Purwokerto.

2. Produk Media Pembelajaran Berbasis IT dengan menggunakan Aplikasi Telegram melalui tahap validasi produk oleh Pembina Pramuka sebagai pengguna dan penanggungjawab kegiatan serta perwakilan Dewan Ambalan dan Anggota Pramuka. Aspek yang menjadi kriteria penilaian ketika validasi yaitu, (a) Aspek Konten dan Isi, (b) Aspek Tampilan, (c) Aspek Penyajian dan Penggunaan, (d) Aspek Bahasa, (e) Aspek Kesan. Dan data hasil validasi kemudian dikonversikan dari data kuantitatif ke kualitatif skala empat.

3. Berdasarkan hasil penelitian dan pengembangan yang telah melalui tahap-tahap pengembangan, antara lain validasi media pembelejaran berbasis IT dengan menggunakan Aplikasi Telegram oleh Pembina Pramuka Kakak F mendapatkan skor 3,20 termasuk kategori "Baik" dan Kakak L mendapatkan skor 3,00 termasuk kategori "Baik" dan 57 Perwakilan Dewan Ambalan dan Anggota Pramuka mendapat skor ratarata 3,14 termasuk kategori "Baik". Dari keempat validator tersebut diperoleh rata-rata skor yaitu 3,11. Skor tersebut menunjukkan bahwa kualitas media pembelajaran berbasis IT menggunakan Aplikasi Telegram pada kegiatan Latihan Jum'at Rutin (Lajutin) Pendidikan Kepramukaan di SMA Negeri 3 Purwokerto termasuk kategori 
"Baik" dan layak digunakan dilihat dari aspek konten atau isi, aspek tampilan, aspek pengunaan dan penyajian, aspek bahasa dan aspek kesan yang didapatkan.

\section{DAFTAR PUSTAKA}

Abimanto, Dhanan \& Mahendro, Iwan. (2021), Penggunaan Aplikasi Telegram Untuk Pembelajaran Jarak Jauh Pada Mata Kuliah Bahasa Inggris Materi Speaking Pada Mahasiswa Universitas Maritim AMNI Semarang. Prosiding Kemaritiman, ISBN : 978-623-94228-2-0

Ariskisaputri, (2019). Pengertian, Fungsi Dan Cara Menggunakan Bot Telegram.

https://www.bukugue.com/apa-itu-bot-telegram/

Brog W,R dan Gall, M.D. (1983). Educational Research: An Introduction. New York : Longman

Fahana, J.F., dan Ridho, F. (2018) Pemanfaatan Telegram Sebagai Notifikasi Serangan Untuk Keperluan Forensik Jaringan, JOM FISIP, 5(1), 1-11

Fitriansyah, Fifit \& Aryadillah (2020), Penggunaan Telegram Sebagai Media Komunikasi Dalam Pembelajran Online, Jurnal Cakrawala, p-ISSN : 1411-8629, e-ISSN : 25793314, Vol. 20 No. 2, September 2020. Online : http://ejournal.bsi.ac.id.ejurnal/index.php/cakrawala

Hidayat, Rahmat. dkk. (2021), Pemanfaatan Quiz Bot Telegram Dalam Pembelajaran Menyimak Bahasa Inggris, Jurnal Penamas Adi Buana, Vol. 4 No. 02, p-ISSN : 26225727, e-ISSN : 2622-5395

Pramudya, K (2020). Artikel Kendala Pelaksanaan Pembelajran Jarak Jauh Dalam Masa Pandemi .April 2020. https://www.researchgate.net/profile/Kevin_Pramudya/publication/340916503

Rois, Ikhwan Nur \& Setiyawan, Cahya Adi, (2020). Penggunaan Aplikasi Telegram Sebagai Media Pembelajaran Pada Mata Pelajaran Bahasa Arab Peminatan di MAN 1 Kulon Progo, Annual Internasional Symposium On Arabic Language, Culture and Literatur. AISALL 2020

Sugiyono, 2009. Metode Penelitian Kuantitatifm Kualitatif dan R\&D, Bandung : Alfabeta

Suyahman, (2020), Pelaksanaan Pendidikan Karakter Melalui Gerakan Pramuka Di Era Pandemi Covid-19, Jurnal Pendidikan, p-ISSN 2715-095X, e-ISSN 2686-5041, Volume 29, No. 2, Juli $2020 \quad(169=176)$, Online : http://journal.univetbantara.ac.id/index.php/jp

Suyanto, (2010), Model Pembinaan Pendidikan Karakter Di Lingkungan Sekolah, Bandung. Remaja Rosda. 